\title{
The Effects of Co-administration of Immobilization Stress and Aloe vera on Serum Carcinoembryonic Antigen in Rats
}

\author{
Rahim Ahmadi ${ }^{1}$; Sedigheh Molaei ${ }^{2, *}$ \\ ${ }^{1}$ Department of Physiology, Faculty of Basic Sciences, Hamedan Branch, Islamic Azad University, Hamedan, Iran \\ ${ }^{2}$ Department of Medical Biotechnology, Iranian Blood Transfusion Organization, Tehran, Iran \\ ${ }^{*}$ Corresponding author: Sedigheh Molaei, Department of Medical Biotechnology, Iranian Blood Transfusion Organization, Tehran, Iran., E-mail: molaei.sedigheh@gmail.com
}

Received: December 12, 2013; Accepted: April 24, 2014

Background: Immobilization has been used extensively and accepted widely for studying stress-induced alterations. To determine the protective effects of Aloe vera leaf extract, we evaluated the effects of co-administration of immobilization stress and Aloe vera leaf extract on serum level of carcinoembryonic antigen (CEA) tumor marker in male rats.

Materials and Methods: In this experimental study, 45 male Wistar rats were randomly divided into 9 groups of 5 rats in each including: 1) control, 2) normal saline receiving, 3) Aloe vera extract receiving, 4) acutely immobilized, 5) chronically immobilized, 6) acutely immobilized+Aloe vera extract, 7) chronically immobilized+Aloe vera extract, 8) acutely immobilized+normal saline and 9) chronically immobilized+normal saline. The animals were exposed to chronic or acute immobilization stress for $2 \mathrm{~h} /$ day or $8 \mathrm{~h} /$ day for a period of 3 weeks or one week, respectively. Aloe vera extract ( $300 \mathrm{mg} / \mathrm{kg} /$ day) was fed by gavage feeding orally. Blood samples were collected and following serum collection, CEA level was determined by radioimmunoassay method. Data were compared statistically between groups using ANOVA.

Results: Serum CEA level was significantly increased in acutely $(0.640 \pm 0.025 \mathrm{ng} / \mathrm{mL})$ or chronically immobilized $(0.647 \pm 0.023 \mathrm{ng} / \mathrm{mL})$ rats compared with control animals group $(0.564 \pm 0.014 \mathrm{ng} / \mathrm{mL})(\mathrm{p}<0.001)$. However, there was no significant difference between serum CEA levels of acutely or chronically immobilized Aloe vera extract received animals compared with control rats $(0.622 \pm 0.027 \mathrm{ng} / \mathrm{m}$ and $0.616 \pm 0.044 \mathrm{ng} / \mathrm{mL}$, respectively).

Conclusion: Our findings indicate that immobilization stress enhances serum CEAlevel, however, intake of Aloevera extract can withstand against.

Keywords:Carcinoembryonic antigen; Immobilization; Aloe vera; Rat

\section{Introduction}

Tumor markers are substances found in the blood, urine, stool or tissues of cancer patients. They are produced by tumor cells or in some cases by the body in response to certain benign conditions [1]. CEA (carcinoembryonic antigen), a surface glycoprotein which was first identified in 1965 is a well-studied onco-fetal antigen [2]. It has been shown that rat CEA has the tissue distribution and physicochemical properties similar to human CEA [3]. Enhanced serum CEA levels occur in a large number of epithelial malignancies, including colorectal cancer [4], gastrointestinal malignancies [5], pancreatic and lung adenocarcinoma [6].

Elevated CEA levels can also occur in patients with noncancerous conditions, including inflammatory bowel disease, pancreatitis and liver disease [7, 8], ageing [9] and alcohol drinking [10]. Many different types of stress trigger changes in the immune system, according to which, there is some link between stress and developing certain kinds of cancer as well as increased serum level of tumor markers. Immobilization is one of the most common performed stresses on animals [11]. Among the various stress models, acute or chronic immobilization has been used extensively and accepted widely for studying the associa- tion between stress and pathophysiological alterations [12]. Immune system suppression in laboratory animals in response to stresses [13], including immobilization stress, may prove this association. Repeated immobilization stress causes structural remodeling in areas of the brain responsible for emotional memories and regulation of the stress response [14]. However, there are studies showing that acute stress enhances immune function but chronic stress suppresses the immune system [15].

Considering botanical agents as medical remedies $[16$, 17], there are several plant species reported to have potential to cure cancers [18] including the oldest and most popular medicinal plant, Aloe vera [19]. Scientists have discovered over 150 nutritional ingredients in Aloe vera. Ten main areas of chemical constituents of Aloe vera include: amino acids, anthraquinones, enzymes, minerals, vitamins, lignins, monosaccharide, polysaccharides, salicylic acid, saponins and sterols [20]. Studies suggest that Aloe vera extract may play an immunomodulatory role against cancer or pathological conditions [21].

Although serum tumor markers assay, in particular CEA, has an important role in screening a healthy population

Copyright (C) 2015, Zahedan University of Medical Sciences. This is an open-access article distributed under the terms of the Creative Commons Attribution-NonCommercial 4.0 International License (http://creativecommons.org/licenses/by-nc/4.0/) which permits copy and redistribute the material just in noncommercial usages, provided the original work is properly cited. 
Ahmadi Ret al.

or a high risk one for the presence of cancer [9], there are few studies examining the relationship between environmental factors and elevated serum CEA levels. There are also few studies examining the antitumorigenic potential of Aloe vera. The reports, however, have established pathophysiological and tumorigenic effects of immobilization stress on animals [22]. In this respect, the present study was exerted to determine the effects of immobilization stress on serum CEA level and possible protective effects of Aloe vera leaf extract against pathophysiological effects of immobilization stress on serum CEA level.

\section{Materials and Methods}

In this experimental study, 45 adult male Wistar rats weighting $190 \pm 10 \mathrm{~g}$ were purchased and raised in our colony from an original stock of Pasteur institute (Tehran, Iran). The temperature was at $20-25^{\circ} \mathrm{C}$ and animals kept under a schedule of $12 \mathrm{~h}$ light: $12 \mathrm{~h}$ darkness (light on at: 8:00 am) with free access to water and standard laboratory chow. Care was taken to examine the animals for general pathological symptoms. Food was withheld for 12-14 h before operation or death. In all experiments, attention was paid to the regulation of local authorities for handling laboratory animals and the Ethical Guidelines for investigation of immobilization stress in rats [23]. This work was conducted in laboratory complex of IAUSR (Tehran, Iran).

In this study, 45 male Wistar rats were randomly divided into 9 groups of 5 rats in each including:1) control, 2) normal saline receiving, 3) Aloe vera extract receiving, 4) acutely immobilized, 5) chronically immobilized, 6) acutely immobilized+Aloe vera extract receiving, 7) chronically immobilized+Aloe vera extract receiving rats, 8) acutely immobilized+normal saline receiving and 9) chronically immobilized+normal saline receiving rats. Animals in the control group received no treatment of any kind. In all Aloe vera extract received groups, Aloe vera leaf extract administered orally at a dose of $300 \mathrm{mg} / \mathrm{kg}$.

Aqueous extract of Aloe vera leaves was prepared according to previous studies with slight modifications [24]. Briefly, fresh Aloe vera leaves weighing between 500-600 g with approximate length $60-80 \mathrm{~cm}$ were collected and the thick epidermis was removed. Fleshy mucilaginous pulp (parenchymatous tissues) was selectively scraped out, homogenized and centrifuged at $6000 \mathrm{~g}$ for $15 \mathrm{~min}$ to remove the fibers. The supernatant was lyophilized. A known amount of extract was suspended in sterilized distilled water used once per day.

In the present study, an immobilization system that allows rats free intake of feed and water while restraining their movement was established. Animals assigned to stress groups underwent immobilization using restraining device. Rats were immobilized but not compressed, pinched, or screaming/screeching. According to previous studies [25], immobilization stress was performed as chronic or acute. In chronically immobilized groups, animals were immobilized $2 \mathrm{~h}$ /day for 3 weeks. In acutely immobilized groups, animals were immobilized $8 \mathrm{~h} /$ day for one week.

Blood samples were collected using cardiac puncture technique after anesthetizing animals by ether. Following serum collection, CEA level was determined by radioimmunoassay method using commercially available kits (Immunotech A Beckman Coulter/ Ref.2121).All results are presented as mean \pm SD. Data were analyzed using SPSS19.0 software. The significance of differences between groups was determined by analysis of variance (ANOVA). Games-Howel test was used for post-hoc comparisons. Differences were considered significant when $\mathrm{p}<0.001$.

\section{Results}

Table 1 represents serum CEA levels in different groups of our study. Our findings indicated that there was no significant difference in serum CEA levels of normal saline received rats compared with control animals. Therefore, feeding method used for extract administration had no significant impact on the results of our study. Furthermore, there was no significant difference in serum CEA levels of Aloe vera extract received animals compared with control rats. Serum CEA level was significantly increased in acutely and chronically immobilized rats compared with control animals $(\mathrm{p}<0.001)$. However, there was no significant difference in serum CEA levels between acutely immobilized and chronically immobilized normal saline received animals compared with control rats. Also, serum CEA levels was lower in chronically and acutely immobilized Aloe vera extracts received rats than chronically and acutely immobilized animals, respectively $(\mathrm{p}<0.001)$.

\begin{tabular}{lcc}
\hline Table 1. Serum CEA levels in control and experimental groups & & \\
\hline Animals & CEA (ng/mL) (mean \pm SD) & p-Value \\
\hline Control & $0.564 \pm 0.014$ & - \\
Normal saline received & $0.535 \pm 0.039$ & N.S. \\
Aloe vera extract (300 $\mathbf{~ m g / k g / d a y ) ~}$ & $0.535 \pm 0.036$ & N.S. \\
\hline Chronically immobilized & $0.647 \pm 0.023$ & $<0.001$ \\
Chronically immobilized+Aloe vera extract $\mathbf{3 0 0} \mathbf{~} \mathbf{~ g / k g / d a y )}$ & $0.616 \pm 0.044$ & N.S \\
Acutely immobilized & $0.640 \pm 0.025$ & $<0.001$ \\
Acutely immobilized+Aloe vera extract $\mathbf{3 0 0} \mathbf{~} \mathbf{m g} / \mathbf{k g} / \mathbf{d a y})$ & $0.622 \pm 0.027$ & N.S. \\
Chronically immobilized+normal saline & $0.641 \pm 0.018$ & $<0.001$ \\
Acutely immobilized+normal saline & $0.642 \pm 0.026$ & $<0.001$ \\
\hline
\end{tabular}

N.S. indicates non significant difference. 


\section{Discussion}

Our findings clearly indicated that immobilization stress results in enhanced serum CEA level whether the stress is acute or chronic. Consistent with our finding, there are reports suggesting that stress can increase tumor growth and tumor marker expression [26, 27]. It has also been shown that chronic stress increases susceptibility for developing pancreatitis in rats, which involves TNF- (tumor necrosis factor-alpha) sensitization of pancreatic acinar cells to undergo injury [28]. However, in contrast to our finding there are studies indicating that chronic stress can strengthen the immune system [15], thereby may cause a resistance to tumorogenesis and forestall against elevating of serum tumor marker levels. Our findings have also shown that despite significant increasing of serum CEA levels in chronically and acutely immobilized rats, there was no significance difference in serum CEA levels of chronically or acutely immobilized Aloe vera extract received rats compared with control animals. This finding suggests that administration of Aloe vera leaf extract withstands against increasing of CEA level caused by immobilization stress, indicating the protective role of Aloe vera leaf extract against potentially tumorigenic effects of immobilization stress. Our data highlight for the first time, to our knowledge, the protective effects of Aloe vera leaf extract on serum CEA level enhancement induced by immobilization stress. In line with this finding, studies have found that Aloe vera extract has a protective role in different organs [29].

The main mode of mechanism of action, however, in one hand, can be thought to be on the reducing effect of immobilization stress on cytotoxic $\mathrm{T}$ lymphocytes and natural killer cells (NK cells) [30] which makes body susceptible to numerous diseases and may result in pathological outcomes followed by increased serum level of tumor markers [31]. On the other hand, Aloe vera plant has more than 60 medicinal active elements [32] and anti-cancer components such as anthraquinones [33] which can suppress tumor progression [34] and forestall against increasing of tumor markers levels in blood.

In conclusion, our findings indicate that immobilization stress has tumorigenic potential to increase serum CEA level and Aloe vera leaf extract administration can withstand against, suggesting the protective effects of Aloe vera leaf extract against tumorigenic conditions. However, further clinical research is required to confirm this finding.

\section{Acknowledgements}

This work was supported by Islamic Azad UniversityHamedan Branch. We should express our hearty thanks to members of laboratory complex of IAU-SR for their helps.

\section{Authors' Contributions}

This work is a product of the intellectual environment of the whole team; and that all members have contrib- uted in various degrees to the analytical methods used, to the research concept, and to the experiment design. All authors have contributed to, seen and approved the manuscript.

\section{Conflict of Interest}

The authors declare no conflict of interest.

\section{Funding/Support}

This paper had been done by personal expenses.

\section{References}

1. Grunnet M, Sorensen JB. Carcinoembryonic antigen (CEA) as tumor marker in lung cancer. Lung Cancer. 2012;76(2):138-43.

2. Selvam NT, Elumalai P, Venkatakrishnan V, Damodarkumar S. Molecular markers in cancer diagnosis and management: A review.J Appl Biol Sci. 2011;5(3):69-74.

3. Abeyounis CJ, Kim JG, Wilhelm SA, Diakun KR, Milgrom F. Carcinoembryonic antigen: a rat model. Immunol Invest. 1989;18(1-4):143-57.

4. Primrose JN, Perera R, Gray A, Rose P, Fuller A, Corkhill A, et al. Effect of 3 to 5 years of scheduled CEA and CT follow-up to detect recurrence of colorectal cancer: the FACS randomized clinical trial. JAMA. 2014;311(3):263-70.

5. Gulley JL, Madan RA, Tsang KY, Arlen PM, Camphausen K, Mohebtash $\mathrm{M}$, et al. A pilot safety trial investigating a vector-based vaccine targeting carcinoembryonic antigen in combination with radiotherapy in patients with gastrointestinal malignancies metastatic to the liver. Expert Opin Biol Ther. 2011;11(11):1409-18.

6. Goggins M. Markers of pancreatic cancer: working toward early detection. Clin Cancer Res. 2011;17(4):635-7.

7. Lee JY, Lee DC, Lee JW. Serum carcinoembryonic antigen is associated with non-alcoholic fatty liver disease in healthy Korean non-smokers. Clin Chem Lab Med. 2013;51(7):1499-504

8. Piraka C, Scheiman JM. New diagnostic imaging modalities for pancreatic disease. Curr Opin Gastroenterol. 2011;27(5):475-80.

9. Ko IG, Park EM, Choi HJ, Yoo J, Lee JK, Jee YS. Proper exercise decreases plasma carcinoembryonic antigen levels with the improvement of body condition in elderly women. Tohoku J Exp Med. 2014;233(1):17-23.

10. Jelski W, Laniewska-Dunaj M, Niklinski J, Kozlowski M, Laudanski J, Szmitkowski M. The alcohol dehydrogenase isoenzyme (ADH IV) as a candidate tumour marker of esophageal cancer. Acta Biochim Pol. 2013;60(3):489-93.

11. Jaggi AS, Bhatia N, Kumar N, Singh N, Anand P, Dhawan R. A review on animal models for screening potential anti-stress agents. Neurol Sci. 2011;32(6):993-1005.

12. Maric D, Kostic T, Kovacevic R. Effects of acute and chronic immobilization stress on rat Leydig cell steroidogenesis. J Steroid Biochem Mol Biol.1996;58(3):351-5.

13. Li T, Harada M, Tamada K, Abe K, Nomoto K. Repeated restraint stress impairs the antitumor $\mathrm{T}$ cell response through its suppressive effect on Th1-type CD4+ T cells. Anticancer Res. 1997;17(6D):4259-68.

14. Miller MM, McEwen BS. Establishing an agenda for translational research on PTSD. Ann NYAcad Sci. 2006;1071:294-312.

15. Dragos D, Tanasescu MD. The effect of stress on the defense systems. J Med Life. 2010;3(1):10-8.

16. Abdollahi A, Fasihi-Ramandi M, Kouhpayeh SA, Najafipour S, Meshkibaf MH, Naghdi M, et al. Antimicrobial effect of 15 medicinal plant species and their dependency on climatic conditions of growth in different geographical and ecological areas of Fars province. Zahedan J Res Med Sci. 2012;14(5):34-7.

17. Imani. E. , Khademi. Z. , Pordadkhodaei A. Blood sugar control and medicinal plants. Zah J Res Med Sci. 2012;13(10):27.

18. Alonso-Castro AJ, Villarreal ML, Salazar-Olivo LA, Gomez-Sanchez M, Dominguez F, Garcia-Carranca A. Mexican medicinal plants used for cancer treatment: pharmacological, phytochemical and ethnobotanical studies. J Ethnopharmacol. 2011;133(3):945-72. 
19. Ahmadi A. Potential prevention: Aloe vera mouthwash may reduce radiation-induced oral mucositis in head and neck cancer patients. Chin JIntegr Med. 2012;18(8):635-40.

20. Dhingra K. Aloe vera herbal dentifrices for plaque and gingivitis control: a systematic review. Oral Dis. 2014;20(3):254-67.

21. Farahnejad Z, Ghazanfari T, Yaraee R. Immunomodulatory effects of Aloe vera and its fractions on response of macrophages against Candida albicans. Immunopharmacol Immunotoxicol. 2011;33(4):676-81.

22. Feng Z, Liu L, Zhang C, Zheng T, Wang J, Lin M, et al. Chronic restraint stress attenuates $\mathrm{p} 53$ function and promotes tumorigenesis. Proc Natl Acad Sci U S A. 2012;109(18):7013-8.

23. Institute for Laboratory Animal Research... Guide for the care and use of laboratory animals. 8th ed: National Academies Press; 2011.

24. Rajasekaran S, Ravi K, Sivagnanam K, Subramanian S. Beneficial effects of aloe vera leaf gel extract on lipid profile status in rats with streptozotocin diabetes. Clin Exp Pharmacol Physiol. 2006;33(3):232-7.

25. Pol O, Campmany L, Gil M, Armario A. Behavioral and neurochemical changes in response to acute stressors: Influence of previous chronic exposure to immobilization. Pharmacol Biochem Behav. 1992;42(3):407-12.

26. Al-Wadei HA, Plummer HK, Ullah MF, Unger B, Brody JR, Schuller HM. Social stress promotes and gamma-aminobutyric acid inhibits tumor growth in mouse models of non-small cell lung cancer. Cancer Prev Res (Phila). 2012;5(2):189-96.

27. Tilan J, Kitlinska J. Sympathetic Neurotransmitters and Tumor
Angiogenesis-Link between Stress and Cancer Progression. J Oncol. 2010;2010:539706

28. Binker MG, Binker-Cosen AA, Richards D, Gaisano HY, de Cosen $\mathrm{RH}$, Cosen-Binker LI. Chronic stress sensitizes rats to pancreatitis induced by cerulein: role of TNF-alpha. World J Gastroenterol. 2010;16(44):5565-81.

29. Beya W, Davidson B, Erlwanger KH. The effects of crude aqueous and alcohol extracts of Aloe vera on growth and abdominal viscera of suckling rats. Afr J Tradit Complement Altern Med. 2012;9(4):553-60.

30. Evans DL, Leserman J, Perkins DO, Stern RA, Murphy C, Tamul K, et al. Stress-associated reductions of cytotoxic T lymphocytes and natural killer cells in asymptomatic HIV infection. Am J Psychiatry. 1995;152(4):543-50.

31. Frick LR, Arcos ML, Rapanelli M, Zappia MP, Brocco M, Mongini C, et al. Chronic restraint stress impairs T-cell immunity and promotes tumor progression in mice. Stress. 2009;12(2):134-43.

32. Bawankar R, Deepti VC, Singh P, Subashkumar R, Vivekanandhan $G$, Babu S. Evaluation of bioactive potential of an Aloe vera sterol extract. Phytother Res. 2013;27(6):864-8.

33. Huang Q, Lu G, Shen HM, Chung MC, Ong CN. Anti-cancer properties of anthraquinones from rhubarb. Med Res Rev 2007;27(5):609-30.

34. Saini M, Goyal PK, Chaudhary G. Anti-tumor activity of Aloe vera against DMBA/croton oil-induced skin papillomagenesis in Swiss albino mice. J Environ Pathol Toxicol Oncol. 2010; 29(2):127-35. 